\title{
'The Instrument of Death': Prison Doctors and Medical Ethics in Revolutionary-Period Ireland, c.1917
}

Weaker and weaker grows the once muscular body of the young Republican, the curly head falls helplessly on the shrunken shoulder and the once red lips are rapidly turning blue. The tube is quickly pulled out, and Thomas Ashe's tortured stomach vomits forth some of the food that has been forced into it. The straps are unbound and the tortured prisoner falls limply forward into a state of collapse. Dr Lowe tells the warders to lead him forth and to leave him down quietly on his bed-he has done his sacred duty and has assuredly earned his five guineas! ${ }^{1}$

In 1917, emerging Irish playwright, Seán Ó’Cathasaigh (or Seán O’Casey), wrote this piercing indictment of his close friend Thomas Ashe's treatment at the hands of the medical staff at Mountjoy Prison, Dublin. Thomas was serving a two-year sentence of hard labour for sedition when he went on hunger strike in protest against the prison authorities' refusal to grant him political prisoner status. As Ó'Cathasaigh lamented, he died soon after being force-fed. Thomas's controversial death was set against a backdrop of mounting political conflict across Ireland as well as the international milieu of the First World War. This chapter examines force-feeding in revolutionary-period Ireland, and the contours added to force-feeding debates as they surfaced in a new national and socio-political context. It focuses specifically on the problem of medical participation in hunger strike management. As demonstrated in the opening chapter, the careers of English prison doctors such as William Cassels gained considerable complexity once the Home Office called upon them to force-feed. Prison doctors 
found themselves subject to public censure, accused of colluding in political agendas, and exposed to legal action. During conflicts, medical professionals are often called upon to aid political and military agendas. Many of them work in prisons and encounter highly politicised prisoners. In these circumstances, their role becomes complicated. Even in 'normal' times, prison doctors operate in a 'dual loyalty' to the ethical norms of their profession and the needs of their institution. As Joe Sim argues, prison doctors have always proactively helped to enforce discipline; they are crucial figures in the disciplining of the body. ${ }^{2}$ According to Sim, prison doctors have not simply benevolently healed prisoners but also helped to enforce the apparatus of physical and psychological control that surrounded them. This situation gains added intricacy in conflict zones, particularly when prison doctors feel obliged to support state objectives. They do things that clash with accepted medical ethical standards and which would seem unacceptable in times of peace. At worst, prison doctors associate themselves with torture. Force-feeding is often considered as one of these lapses in medical ethics.

In the years preceding Thomas Ashe's death, the suffragette movement had made considerable inroads in Ireland. ${ }^{3}$ The apparent imminence of Irish independence had produced opposing perspectives on whether Ireland should be autonomous from the UK. ${ }^{4}$ In response, two paramilitary forces came into existence prior to the outbreak of war: the Ulster Volunteers-formed to help maintain the Union with Britain-and the Irish Volunteers, a group co-founded by Thomas with the agenda of forcefully securing national independence. ${ }^{5}$ During the First World War, the constitutional path to Irish independence supported for some decades by the Irish Parliamentary Party was severely undermined by militant republicanism. ${ }^{6}$ In the 1910s, the Irish Republican Brotherhood (IRB) (later renamed as the Irish Republican Army or IRA) adopted a violent approach to securing independence and staged the Easter Rising in 1916.7 From the mid-1910s, republicans sought to undermine the legal and judicial systems established in Ireland by the British government. Hunger striking was central to their effort. ${ }^{8}$ Thomas Ashe was among the first known casualties of prison force-feeding. ${ }^{9}$ Like other hunger strikers, Thomas chose to self-mutilate and disfigure his own body by starving in a public spectacle of self-defacement. In an effort to restore digestion, prison doctors tackled the protest with their stomach tubes.

But what implications did the exigencies of conflict have for prison doctors dealing with hunger strikers? This chapter addresses this question 
using the case study of a doctor employed at Mountjoy Prison, Dublin: Raymond Granville Dowdall. By chance of being employed in a prison during a period of political tumult, Dowdall came face-to-face with an array of politicised prisoners, including suffragettes, labour leaders, and republicans. Many of these staged hunger strikes and were force-fed by Dowdall. Dowdall was forced to negotiate his precarious position as intermediate between the state and the fasting prisoners under his care. Yet Dowdall harboured negative attitudes towards politicised prisoners. Doctors do not always act neutrally; they share attitudes towards certain patients which can affect treatment. This is particularly the case at times of conflict when the willingness of prison doctors to adhere to medical ethical norms can be compromised by the specific socio-political context in which they work and reside. Unfavourable attitudes towards prisoners deemed 'terrorists' or 'dissidents' can encourage severe institutional treatment, especially if medical staff support government agendas. During civil conflicts, notions of the 'terrorist' shape doctor-patient interactions. Even physicians who normally adhere to the bioethical guidelines of their profession can experience serious ethical and psychological discord when dealing with individuals who have perpetrated violence, often against the members of their own communities. ${ }^{10}$ Anger and disdain might be felt by a doctor who believes that a 'terrorist' is undeserving of his or her assistance. At worst, (s)he might turn a blind eye to violence inflicted upon certain prisoners. ${ }^{11}$ At the time of writing, this problem is endemic at sites of incarceration including Guantánamo. Yet the problem is far from new. In the past, it encouraged a propensity to use force-feeding as a punitive, rather than therapeutic, mechanism.

Much depends on context. Force-feeding has been performed, experienced, and represented in contrasting, but deeply meaningful, ways. In the 1910s, different types of bodies were force-fed: male and female bodies; English and Irish bodies; wartime and peacetime bodies; suffragette and republican bodies. Different meanings came to be applied to the various types of force-fed bodies, depending on considerations such as gender and political identity. In the early 1910s, the Home Office sought to protect the weakened suffragette hunger striker from a self-imposed death, if only to avoid martyrdom. Her femininity played an important role. Yet prison doctors such as Dowdall performed force-feeding less carefully on male Irish republican bodies, a problem that resulted in death. Ultimately, Thomas Ashe's corpse came to be imbued with qualities of self-sacrifice and heroism in the face of an unrelenting government. As this chapter 
also suggests, Thomas's death had important professional implications for Dowdall and his colleagues who were called upon to provide evidence in a remarkably well-publicised and deeply contentious inquest. Their willingness to force-feed on behalf of the British state reverberated in revolutionary-period Ireland. As force-feeding crossed national boundaries, the procedure was no longer something done to recalcitrant, seemingly erratic, British women; it evolved into an act that symbolised the apparent threat posed by Britain to the sanctity of Ireland as a whole. Thomas's death held national meaning; his corpse illuminated the aggressiveness of the British government and its willingness to murder Irish men rather than grant them independence. In republican rhetoric, the stomach tube itself became a powerful political symbol; it transformed into a medical technology deeply imbued with political connotations. In using the stomach tube, Dowdall and his colleagues found themselves at the crossfire of this highly politicised scenario.

\section{Suffragette Force-Feedings in Ireland}

Dowdall pursued a career in prison medicine during a period of deep political tumult. At the start of the century, Dowdall was a well-respected public figure. Coroners regularly called upon him to provide evidence at inquests in Dublin. He was also a key Irish witness at the Royal Commission on the Care and Control of the Feeble-Minded between 1904 and 1906. ${ }^{12}$ Although little is known about his private life, census records reveal that Dowdall was a single Protestant who turned fifty in 1908 who lived with his housekeeper Catherine Gilbert. ${ }^{13}$ Prison medical services at Mountjoy were somewhat lacking. In the earlier stages of his career, Dowdall found himself at the centre of a number of controversies. In 1903, a female prisoner died at Mountjoy while serving a short fourteen-day sentence. Upon noticing her fading health, Dowdall consulted a second doctor who advised him that the prisoner's only hope of survival rested in a major operation for acute intestinal obstruction. The prison lacked the resources required to undertake this procedure. Although a jury later absolved Mountjoy's medical staff of blame for the prisoner's death, it highlighted a lack of medical facilities at the prison that might have saved her life had they been in place. ${ }^{14}$ Five years later, prisoner Richard O'Brien died suddenly of heart failure. The medical officer in charge, Dr Paisley, had announced midway through his shift that he was leaving the prison to attend the University Club in Stephen's Green. Paisley returned considerably later than expected 
with a strong smell of alcohol on his breath to learn that O'Brien had unexpectedly passed away. The prison staff incurred the wrath of Dowdall who, upon asking Mr Gamble, the prison clerk, 'why did you not telephone for me?', was informed that the Chairman of the Prisons Board did not recognise the use of the public telephone. ${ }^{15}$

As Ireland's socio-political climate changed, Dowdall began to encounter prisoners with strong political views. The Irish female suffrage movement formally emerged in 1876 when Quaker feminist, Anna Haslam, founded the Dublin Women's Suffrage Association, renamed the Irish Women's Suffrage and Local Government Association in 1911. Despite its modest beginnings, the Association attracted a significant number of new members in the opening decades of the twentieth century. ${ }^{16}$ Hanna Sheehy-Skeffington and Margaret Cousins founded the Irish Women's Franchise League in 1908. ${ }^{17}$ In summer 1912, Irish suffrage groups organised a number of peaceful protests which were overshadowed by the violence wrought by English WSPU members, Mary Leigh, Gladys Evans, and Lizzie Baker. The women not only threw a hatchet at Prime Minister Herbert Asquith and John Redmond, leader of the Irish Parliamentary Party but also tried to set fire to the Theatre Royal in Dublin. Lizzie Baker was convicted of conspiracy and given a sentence of seven months' hard labour. Mary Leigh and Gladys Evans were convicted of conspiracy, arson, and explosive charges and awarded five years' penal servitude, the lengthiest prison sentence given to a suffragette. ${ }^{18}$ As George Bernard Shaw pointed out in a letter published in the Irish Times, the severity and length of the sentencing rendered force-feeding problematic. Prisoners, he remarked, could not be kept alive with force-feeding for five years. Nor could they be released for such a serious crime. ${ }^{19}$ Yet the Home Office was determined to keep female hunger strikers alive to avoid martyrdom and circumvent public opinion turning firmly against its contested policies. ${ }^{20}$

At Mountjoy, the prisoners went on hunger strike and encountered Dowdall. The medical reports recorded by Dowdall during their feedings provide a rare portal into force-feeding from a doctor's perspective. They are challenging to interpret, but deepen and complicate propagandist suffragette claims of torture and abuse. They suggest that force-feeding was not always the haphazard, coercive process depicted by outraged suffragettes. Mary Leigh's medical report demonstrates that force-feeding could be a closely regulated, technological procedure that incorporated a range of diagnostic and observational medical techniques designed to monitor prisoner health, if only to avoid prison fatalities. It was not simply the case 
that doctors carelessly crammed a tube into the gullet of female patients, aiming to cause as much pain and discomfort as possible, despite suffragette claims. However, the high levels of care taken by Dowdall could be ascribed to political context. As William Murphy observes, hunger striking suffragettes serving sentences in Irish prisons tended to be treated more compassionately than their English counterparts. ${ }^{21}$ The high levels of media attention directed towards the prisoners cast Dowdall in the public spotlight. It is likely that he took particular care while feeding to avoid negative publicity or injury. Moreover, Dowdall was in close contact with Dublin Castle and the Home Office who received regular reports on the health of hunger striking suffragettes. He was under close observation.

How did Dowdall perform force-feeding? Prior to feeding Mary Leigh, Dowdall, Joseph O'Carroll of Richmond Hospital, and two prison medical officers carefully examined her for symptoms of organic disease. They measured her pulse, temperature, weight, and the gravity of her urine and its albumen and sugar content before deciding to 'artificially feed' her. Before commencing the procedure, the two medical officers loosely strapped Mary in a chair while preparing a funnel and soft rubber tube for her nasal feeding. They heated Mary's food-consisting of ten ounces of milk with one beaten up egg-to $98.4^{\circ} \mathrm{F}$ and fed her twice a day. Dowdall added medicines - bismuth and cascara - to his patient's food as required. On each occasion before administering food, he carefully examined Mary, meticulously recording her temperature, pulse, and weight.

Dowdall seemed to have approached (or at least recorded) his task as a medical procedure rather than a purely punitive one and paid close attention to his patient's health. Yet although Dowdall ostensibly sought to preserve his patient's health, he found that he could do little to stem the negative physical and emotional effects of force-feeding. A considerable degree of bodily manipulation was required for the procedure to run smoothly. Throughout her feeding, Dowdall failed to curb Mary's intense vomiting caused naturally by the rejection of the stomach tube and its contents by her body. To counter this relentless vomiting, Dowdall tried feeding Mary with foods of different temperatures. When this failed, he experimented with introducing food into the tube at various speeds. On one occasion, he kept his patient in the chair for an hour and fed her slowly under the hope that this might contain her vomiting. He then tried a slow feeding period lasting two hours, also to no avail. Dowdall's final step involved purchasing a special chair from Messrs Carter of London that allowed Mary to rest on her back after being fed. This also failed to stem Mary's vomiting. 
Dowdall's perception of his work appears to have been deeply informed by his gendered perspectives on the behaviour and mental health of militant women, as evidenced by the comments which he sketched on his patient's medical report. 'The act of evacuating the contents of the stomach', explained Dowdall, 'cannot in this woman's case properly be described as vomiting. The liquid food wells up in to the mouth and is expelled by her. It is more akin to the vomiting of hysteria'. This latter comment suggests that Dowdall subscribed to a popularly held perception of the suffragette as hysterical, excitable, and irrational, an idea commonly referred to when explaining her violent tendencies. ${ }^{22}$ As Rachael Russell notes, it was not uncommon for psychiatrists to interpret vomiting as a symptom of hysteria, as a product of the reflex action of the brain. Unlike normal vomiting, hysterical vomiting was sudden and unexpected. The stomach simply emptied itself. ${ }^{23}$ It is likely that Dowdall's perception of his patient as hysterical legitimated his view of the procedure as a medical necessity that needed to be enforced upon a mentally unstable patient whom he had a duty to care for. Casting his patient as hysterical also allowed Dowdall to divert blame for her body's adverse response to the feeding tube to the patient's poor mental health, not the feeding process. Dowdall also noted that Mary developed convulsive seizures while being fed. The first of these seemed to resemble tetanus; two subsequent seizures bore resemblance to the convulsions of hysteria. Arms flexed at the elbow, hands clenched, and both feet extended in a state of tonic spasm, Dowdall subjected Mary to a further five minutes of feeding. After he completed his task, Dowdall recorded: 'No appearance of pain caused by the nasal tube or any complaint of pain by the patient. No palpitation, irregularity of the heart, collapse, weakness or icy coldness of the extremities. No injury has been inflicted on the nasal passage or any bleeding. ${ }^{24}$

Interpreting this medical report presents problems. It is tempting to swiftly demonise Dowdall as a harsh, unfeeling, brutal individual who perhaps took great pleasure in the task newly assigned to him, following the lead of suffragette activists who routinely castigated prison doctors as torturers in their propaganda. ${ }^{25}$ Adopting a gendered perspective, Dowdall could be portrayed as a dominating male medical figure eager to subject his unfortunate female patient to an array of medical and technological procedures applied relentlessly even despite the obvious trauma, pain, and vomiting being caused by the procedure. There is also an experimental aspect to Mary Leigh's force-feeding; her body became an object that was restrained, observed, manipulated, and tested for its ability to withstand 
force-feeding. The emotions experienced by Mary during this handling of her body are left mostly unrecorded. However, can a certain extent of care-giving be detected in Dowdall's actions? One alternative reading would be that Dowdall took considerable care to measure his patient's health, temperature, and weight. He paid scrupulous attention to the amounts of food being inserted into the tube, its contents, and the speed in which it was inserted, and even obtained a chair from London to ease his patient's discomfort. Regardless of his motivations for keeping Mary healthy, she presumably interpreted her endless vomiting and the insertion of an intrusive tube into her body as emblematic of the state-sanctioned brutality which she found herself exposed to. Mary was eventually released from Mountjoy on licence following a consultation between President of the Royal College of Surgeons in Ireland, Thomas Myles, and renowned Mater Hospital physician Christopher Nixon. Prison doctors transferred Mary to the nearby Mater Hospital in a debilitated condition, too weak to stand up without help and in a state of collapse. ${ }^{26}$ In the following month, Gladys Evans was discharged in a similar condition. ${ }^{27}$ Force-feeding appears to have done little to improve or uphold bodily health, despite Dowdall's efforts to avert vomiting and pain.

\section{Republican Force-FeEdings}

The value of having such a vivid account of Mary Leigh's experiences is that it allows for comparison with other politicised prisoners fed by Dowdall. In turn, evidence can be pieced together about the fraught relationships forged between Dowdall and the politicised prisoners whom he encountered. Dowdall seems to have acquired a taste for force-feeding. During the Dublin Lockout of 1913, he fed prisoners including Arthur Fagan who swiftly resumed eating and promised to behave. ${ }^{28}$ In 1913, Dowdall force-fed labour leader, Frank Moss, for nine days followed by a lengthier period of eighteen days. ${ }^{29}$ Upon being released, Frank recalled to the Daily Herald that on one occasion Dowdall had lost his temper while experiencing difficulty inserting a nasal tube. Frank vividly described the sensation of Dowdall's failed attempts at insertion. He claimed that he 'seemed to feel something snap in his head' and that the agony continued when he was returned to his cell 'as if his brain was going'. 'I did not mind dying', he lamented, 'but I wanted to die sane'. ${ }^{30}$ Two years later, Dowdall announced his desire to feed prominent Irish pacifist, suffragist, and writer Frances Sheehy-Skeffington, although the Chief Secretary 
of Ireland, Augustine Birrell, directed against this, presumably due to Sheehy-Skeffington's high public profile. ${ }^{31}$ Evidently, Dowdall was firmly immersed in the political dramas of the day. As Mountjoy's chief medical officer, he came into contact with leading feminist, labour, and republican activists armed with his stomach and nasal tubes. He seemed undeterred by the intricate ethical discussion about the potential dangers of forcefeeding taking place in England and proved himself as a formidable opponent for many politicised prisoners who refused to eat.

It is difficult to determine whether Dowdall truly believed in his medical duty to save the lives of 'suicidal' prisoners or if he recognised the punitive value of feeding technologies in disciplining recalcitrant prisoners. What does seem clear is that Dowdall paid considerably less attention to the health and well-being of non-suffragette prisoners. Perhaps this was because the Home Office and Dublin Castle were less concerned about the health of republican prisoners than the suffragettes? Under less government scrutiny, Dowdall had free reign to perform the procedure as he wished. Or perhaps he felt more comfortable inflicting pain on a male body? Could it also be that Dowdall felt more invested in tackling Irish labour and republican prisoners? It is plausible that Dowdall had little interest in the cause of female suffrage, given that the movement was relatively less disruptive in Ireland. In contrast, republicanism posed a threat to the political and social structure of his nation. In the 1910s, it was presumably difficult not to hold an opinion on Irish independence. As a Protestant who had partaken in government Commissions, it seems likely that Dowdall felt at least some attachment to the existing political establishment that employed him. But did this worsen disciplinary conditions for the republican prisoners whom he fed?

Irish republicans began hunger striking following the Easter Rising. In 1917, forty prisoners were force-fed. ${ }^{32}$ Historian George MacSweeney presents republican hunger strike as an integral part of Irish history and mythology and argues that republicans including Thomas Ashe chose to refuse food in light of the influence of a national revival in traditional Gaelic cultural practices. ${ }^{33}$ However, it seems more conceivable that republican prisoners were cognisant of the recent efficacy of the suffragette hunger strikes in garnering public attention and sympathy. As Murphy suggests, suffragette hunger striking provided a template referred to by republicans during their campaign for independence. ${ }^{34}$ Irish republicans knew full well that force-feeding brought state policies into question and severely disrupted prison management. Nonetheless, war had now hardened the 
attitudes of state bodies and prison authorities to prison militancy and also towards republicanism, viewed from British and unionist standpoints as a betrayal to the more urgent cause of defeating German aggression..$^{35}$

The idea that Irish citizens were being fed against their will prompted an emotional public response rooted in sympathy for those imagined to be in physical and mental agony. Republican hunger striking was influenced by a vastly different set of gendered considerations than their suffragette equivalents. The issue of maltreating a female suffragette body had been deeply inflected by consideration of her femininity. Performing force-feeding on a female prisoner-deemed frailer and more physically vulnerable than her male counterpart-carried different connotations than subjecting a male prisoner to the same procedure. The Irish republican was stereotypically strong, muscular, and male, an image which Sikita Banerjee denotes as 'muscular nationalism'. ${ }^{36}$ In light of this, male republicans were presumed to be able to endure pain and discomfort, to withstand the procedure of force-feeding. Less therapeutic care was needed.

However, male republican prisoners also experienced force-feeding as an emotional and physical violation. Austin Stack, for instance, had been politically active since 1908 and joined the IRB in 1916 while acting as the commandment of the Kerry Brigade of the Irish Volunteers. In 1916, Austin was arrested and sentenced to death due to his involvement in the Easter Rising, although his sentence was commuted to penal servitude for life. He went on hunger strike in May 1917. Austin recorded his experiences of being fed in pencil on a sheet of poor quality paper (possibly toilet paper) which he intended to smuggle out of the prison to reach Thomas's sister Nora. Lamenting his encounter with the tube, Austin scrawled:

We resisted being carried to the operation room on Saturday evening when forcible-feeding began. Each of us was strapped arms and legs to a chair. I was fed on this occasion by Dr Cooke. It was very painful. My eyes watered during the whole time so that I could see nothing. I vomited during and after the process so that not one half of the food entered my stomach. My clothes were covered with the stuff. There was no attempt made to examine me or even to check my pulse before I was fed. On Sunday morning I was fed by Dr Dowdall. He was longer about the work and caused me even more pain than Dr Cooke. I said to him when he was trying to get the tube down my throat: 'the other doctor' (I did not then know Cooke's name) 'did not have half the difficulty'. Dowdall replied 'that may be' and went on with the work. ${ }^{37}$ 
Recollections made by other force-fed prisoners (contained in the Bureau of Military History oral history interview collection) further demonstrate that male prisoners experienced the procedure as a physical and mental assault upon their bodies, as a thoroughly degrading and brutal emotional experience. Eamon O'Dwyer later recounted that:

Each man in turn was brought to a large room in which they had the usual
operating chair. We were tied into this chair with bands around the legs and
arms, a band around the body and also a band around the neck, and into
each man's mouth an instrument was passed to keep it open. The forcible-
feeding outfit was brought along - a pint of milk with an egg broken into it,
the pump and the tubing. The tubing was passed down through the mouth
and into the stomach. I never had any fear of hunger striking and that was
the first one, but I certainly did not like this pipe being passed down through
my throat and I began to have a horror of it. I must admit that I was very
much afraid of it, and often in years afterwards I woke up and felt this damn
pipe or tube going down my neck like a snake. Every one of the crowd who
suffered this vomited terribly. The days passed with this [force-feeding] as
the only relief from the monotony of being held in the cell.

For Eamon, force-feeding was not only highly uncomfortable but also left a lasting emotional and psychological impression. As the experiences of William Ball had demonstrated, male mental distress following forcefeeding was hardly unknown. Even despite recent evidence to the contrary, the mental stamina of male prisoners was expected to be robust, whereas the psychological instability of female prisoners was taken almost for granted. This indifference was also reflected in the relatively low levels of therapeutic attention awarded to male republicans by Dowdall and his colleagues in comparison to their female suffragette counterparts. Republican prisoners expressed deep concern over the limited attention being paid to their well-being. When scrawling his message to Nora Ashe on his prison paper, Austin Stack recorded that one of the male prisoners suffered from a weak heart. He advised his fellow prisoner to 'demand the attendance of an indifferent doctor', a clear reference to the sense felt by Austin that their treatment was being dictated, in part, by the conflicting political perspectives of doctors such as Dowdall and, perhaps, the objection of the medical staff to the upheaval created by events such as the Easter Rising of 1916 which Thomas Ashe and Austin Stack had both been involved in. ${ }^{39}$ 
It is important to note that this hostility and indifference towards republican prisoners was not endemic among all of the prison staff, a scenario that illuminates the complex relationships formed between prisoners and staff. Patrick J. Berry had joined the prison service as a warder in 1906 and became friendly with Thomas Ashe during 1917. He appears to have been sympathetic to the prisoners and their cause given that he later joined the IRB. Berry later recalled:

On the Sunday morning when they were bringing him down to the surgery room to administer the forcible-feeding by Dr Dowdall, it was I who took him down and I told him to give the doctor a bit of his mind. When he went in, the doctor asked him to take his food voluntarily. Ashe replied "no". Then the doctor said "If not I have no other alternative but to feed you forcibly". Thomas Ashe then said to the doctor [that] he would go down to posterity crowned with the blood of innocent Irishmen on his soul. He fed him through the mouth then and after that Ashe walked back to his cell. ${ }^{40}$

A shift in the behaviour of the medical staff occurred midway through the 1917 hunger strikes. Dowdall passed responsibility for feeding to $\mathrm{Dr}$ Lowe, a local physician who Patrick later denounced as 'a man who knew nothing about forcible-feeding'. This decision was made after Cooke failed to arrive at work after receiving a warning to not go near the prison. ${ }^{41}$ Prison doctors working in times of civil conflict often find their lives at risk, particularly if members of the public view them as complicit in torture or harsh punitive regimes. This was certainly the case in 1917 when doctors who force-fed could be viewed as akin to torturers. Although this death threat was presumably intended to ameliorate the situation of the prisoners by discouraging further feedings, it inadvertently led to a less experienced doctor being called in to undertake a procedure normally performed with greater care by the experienced Dowdall and Cooke. As Austin Stack wrote:

I was fed that morning by a strange young doctor, whose name I subsequently learned was Lowe... The doctor did not examine me in any way, but he felt my pulse. This was the first time any of the doctors had done even this with me. So far as I recollect he did not ask me any questions. He tried to put the tube down my throat for a long time and caused me very much pain. The hospital orderly kept my mouth open with a spoon lest I might take off the fellow's finger which he was putting down my throat for part of the time so that I felt almost strangled. After he had put down the tube 
a little way or the whole-I could not tell which-twice or three times, he took it out again.

The second or third occasion I vomited some stuff and thought the operation was over until he came to renew the efforts. I said, "I thought it was all over. The other doctors had not anything like this difficulty in feeding me". "Dr Cooke", I added, "is able to get down the tube without half the trouble". "Which side does he put it down?" asked Lowe. "Straight down my throat", I told him. He then went to work again and I suffered indescribable pain while he fiddled with his finger and with the tube to get the tube down my throat. Eventually, the thing was at an end and I vomited about half of what had been pumped into me. The reason why I could not say whether I was fed or not after his earlier effort was due to the pain I lost my senses for the moment. I was unable to see anything on account of water running from my eyes. ${ }^{42}$

If Austin's account can be taken at face value, the prison medical staff had brought in a relatively inexperienced doctor to undertake a procedure which required care and technical skill. The doctor caused levels of physical agony which Austin struggled to translate into words. Lowe persevered with force-feeding despite the severity of Austin's physical and emotional distress.

\section{Thomas Ashe's Inquest}

It seems clear that republican prisoners experienced a similar range of emotions to their suffragette counterparts while being fed by Dowdall and his colleagues. They felt fear towards the stomach tube, apprehension about its insertion into their bodies, and distress at the pain caused as liquid food poured through their digestive tracts. Yet they experienced a stronger sense that force-feeding was not being used solely for medical purposes. If anything, republican prisoners felt disdain at the lack of medical attention provided by Dowdall, contrasting sharply with the close levels of medical superintendence awarded to Mary Leigh. Indeed, republicans experienced force-feeding as part of a broader regime of punishment and discipline enacted upon their bodies. This feeling strengthened when Lowe fatally fed Thomas Ashe. The potential dangers of force-feeding were now irrefutably clear; Lowe's inexperience and carelessness had caused a death, bringing Mountoy's medical staff into public disrepute.

Dowdall now found himself allegedly complicit in a broader political agenda of subjugating Irish rebellion. Rather than having acted 
autonomously as part of the medical profession, he was now decisively cast as a doctor who had willingly abandoned the long-established medical ethical norms of his profession to force-feed. For a number of years, doctors who force-fed prisoners had clung to their argument that they had a duty to provide medical treatment when lives seemed endangered. Yet the boundaries between force-feeding as therapy or torture swiftly closed once Thomas's death made clear that the procedure could kill, if performed haphazardly. In this context, Dowdall's feedings came to be viewed as part of a broader discriminatory prison regime supported by the state that supported disciplinary techniques marred by violence and brutality.

Thomas Ashe's death prompted a passionate public response (buttressed by republican cries of murder) which transformed the prison fatality into a national tragedy in which all 'true' Irish citizens were expected to emotionally engage. National and local newspapers reported daily on the controversial inquest proceedings that followed Thomas's death. The inquest was a public display of anger, sentiment, and grief in which far broader debates about British presence in Ireland were played out. Republicans used the inquest to galvanise public feeling against British rule. ${ }^{43}$ To ensure that the public remained aware of its outcomes, the proceedings were published in pamphlet format. The result was a significant historical text that provides a unique insight into early twentieth-century Irish medical ethics and prison medical practice, albeit one which British authorities sought to destroy as many copies of as possible. ${ }^{44}$

In its preface, the pamphlet's editor asserted that Thomas's death was 'a graphic example of British government and Irish officialism in their operation'. 'A Government instinctively alive to its own interests and to the interests that it is supposed to represent in Ireland would have averted the disaster' explained the author, adding that 'apologists describe it as a "regrettable accident" but it was one of those accidents that was inevitable under the system of government that exists in Ireland'. As the author elaborated, 'the treatment of Thomas Ashe reveals a carelessness of consequences and a worship of the iron regulation which in themselves must make the detailed administration of Irish government a ceaseless and hopeless provocation of popular antagonism. ${ }^{45}$ Evidently, Thomas's death provided a suitable trope for casting wider judgement on the nature of British rule in Ireland in a period of burgeoning national political and social turmoil. ${ }^{46}$ Indeed, the inquest essentially served as a forum at which broader tensions between nationalist and unionist communities were rehearsed. The editor portrayed force-feeding as emblematic of the 
inhumanity inherent in British governance and as further justification for the need for political independence, a step that firmly implicated Mountjoy's medical staff.

The inquest continued a conversation initiated by the suffragettes in 1909 on technical matters relating to the safety of force-feeding and the extent to which the procedure fitted with contemporary medical ethics. Yet unlike the formal proceedings of Leigh v Gladstone in 1909, opponents of the practice now had the evidence of death on their side. Moreover, the harsher treatment meted out to Irish republican prisoners (due, in part, to institutional violence enacted upon men being less controversial than on women) ensured that a weightier catalogue of violence and intimidation was available as damning supporting evidence. Moreover, the idea that the British establishment supported a prison network so intent on disciplining that it willingly resorted to torture and intimidation (including forcefeeding) imbued the inquest with deep political resonance. The state, it seemed, was quite happy to use its prison staff as puppets to maim and kill its political opponents. The stomach tube was now firmly embroiled in a centuries-old debate on British rule.

At the inquest, Timothy Healy acted as counsel for Thomas's family. As an MP for the Irish Parliamentary Party, Healy had firm republican credentials. Healy single-handedly transformed the inquest into an arraignment of British rule. ${ }^{47}$ Like many English critics of force-feeding, he sought to establish the procedure as dangerous and incompatible with normal medical ethical practice. However, Healy went further. He claimed that force-feeding amounted to torture, seemingly exposing the human cost of Britain's incursion into Ireland, casting Dowdall as a puppet in a far broader political game. Ulster Unionist Henry Hanna represented the Crown and unsuccessfully tried to ensure that witnesses at the inquest discussed only the immediate cause of Thomas's death, not its broader political implications. ${ }^{48}$

The inquest was politically and emotionally charged. Healy commenced by calling upon John Irwin to provide evidence. Irwin had served as Chairman of the Visiting Committee of Prisons when Mary Leigh had been force-fed. During the republican feedings, he had visited the prison with medical doctor Kathleen Lynn and Thomas Myles to warn staff about the potential dangers of force-feeding. Irwin had personally witnessed the physical and emotional effects of force-feeding in asylum practice and during the suffragette hunger strikes. Healy's questioning revealed harrowing issues about Thomas's death. It transpired that Thomas's bed and 
bed-clothing had been removed on the two nights immediately preceding his feeding, a punishment that had prompted Irwin and the Lord Mayor of Dublin to head to Dublin Castle to remonstrate. ${ }^{49}$ Thomas's body had not only been force-fed but also subjected to a range of physical and mental punishments that had lowered his physical and mental stamina. This supporting evidence indicated that, in this instance, force-feeding formed part of a far broader disciplinary regime for Mountjoy's politicised prisoners. In turn, this raised the problematic question of why Dowdall had authorised force-feeding on an already debilitated individual.

Professor Edmund Joseph M'Weeney, pathologist at National University Dublin and the Mater Hospital, provided further disquieting evidence. M'Weeney had been tasked with examining Thomas's corpse. At the inquest, he described the corpse as muscular and well-developed with few signs of emaciation. He recounted having seen superficial scratches around Thomas's jaw, nine superficial excoriations on his chin, scratches on his lips, and number of small excoriations visible around his Adam's apple. M'Weeney reported that a depression 'not unlike the mark of a thumb nail' had been perceptible below Thomas's thyroid cartilage. M'Weeney concluded that Thomas's death had resulted partly from syncope owing to the failure of a weak and slightly dilated heart and partly from passive congestion and oedema of both lungs. ${ }^{50}$ The violence enacted upon Thomas by Dowdall, Cooke, and Lowe had been rendered visible; force-feeding had left physical scars in addition to the emotional scars reported by prisoners including Austin Stack. Thomas seemed to have been 'force'-fed rather than 'artificially' fed.

But had the force-feeding actually killed Thomas? A protracted debate ensued about Thomas's heart, which M'Weeney noted to have been three ounces above the average weight of a male heart. Thomas, M'Weeney commented, was a man of excellent physique, if slightly fat. 'One would expect a large heart to go with a large physique,' he explained. When asked how long a well-nourished man with a fairly fat physique could withstand hunger, M'Weeney made clear his view that 'the deceased did not die of hunger' but instead from congestion of the lungs brought about by having been force-fed before his weak, dilated heart failed. 'I consider that a man of that type of heart', explained M'Weeney, 'would be very apt to succumb to any sudden shock or to any prolonged physical struggle which he might have to go through', adding that even if the prison medical staff had actually taken the time to examine Thomas's heart prior to feeding, it was unlikely that they would have detected its 
true state of health by auscultation. ${ }^{51}$ M'Weeney's views on the role of shock in increasing susceptibility to heart conditions corresponded with contemporary medical thought on the relationship between the emotions and heart conditions. Various esteemed physiologists (most notably William Osler, Clifford Allbutt, and William Sadler) ascribed sudden heart failure to mental stress and strain, to physical exertion coupled with mental stress. They understood heart conditions as simultaneously emotional and physical. ${ }^{52}$ In McWeeney's view, the mental and emotional shock which Thomas had been continually exposed to in prison had predisposed him to a sudden and fatal heart condition. The very fact that forcefeeding had broken down the body of a stout, muscular, and masculine male republican bore testimony to the apparent viciousness and danger of the practice when used on prisoners, something which critics across the British Isles had argued for almost a decade. Following McWeeney's evidence, Healy vehemently announced that the British state had managed to murder Thomas.

By this stage of the inquest, it seemed clear that Thomas had died from complications with the forceful insertion of a stomach tube. Hanna insisted that Thomas had not been force-fed but, on the contrary, had refused to feed himself. He also pointed out that the prison had been in a state of pandemonium due to the hunger strikes, stating that 'the whole prison system and Government could not be held up because these men refuse to take food for two days'.$^{53} \mathrm{He}$ then made the case that Dowdall, Cooke, and Lowe had simply tried to fulfil their medical ethical duties to sustain life in highly unusual and challenging circumstances. 'If these men [the prisoners], in times like these', asserted Hanna, 'endeavour to raise sedition and disaffection amongst his Majesty's subjects, they had no reason to complain that the law that they were up against-so long as it had power-must be enforced'. Hanna evoked the broader crisis of the First World War to further justify force-feeding. For him, the infliction of pain on recalcitrant prisoners to quell Irish rebellion was more than welcome at a time when Britain and Ireland were confronted with the far broader problem of international war. Yet Hanna's claim that the doctors had performed a safe, therapeutic procedure seemed unconvincing given the cuts and bruises evident on Thomas's body and the fatal damage done to his inner body. Healy persisted in disrupting Hanna's interpretation of prison events. 'I want the instrument that killed him', Healy demanded to Dr Lowe at one point, 'the instrument of death-I want to find out your experience as a "pumper". ${ }^{54}$ 
Under considerable pressure, Dowdall provided evidence and stood by his argument that he had been required to authorise 'artificial feeding' in line with his ethical and professional duty to sustain patient health. Nonetheless, he struggled to explain why he had decided to feed Thomas after two days of solitary confinement without a bed, bedding, or boots. ${ }^{55}$ Hanna then called in Dr Kinsella, prison medical officer at Maryborough Prison, who informed the inquest that he had once fed a prisoner artificially for nearly two years, adding that this individual had even gained weight in that time. In response, Healy furiously asked: 'Before you fed your patients artificially did you put them naked in a cell and deprive them of their bed, bedding, boots and clothes for fifty hours? ${ }^{56}$ Following a number of similar assertions, Hanna jumped to his feet, announced his objections to the repetition of words such as 'killed' and 'murdered', and stormed out of the inquest. ${ }^{57}$ Sensing the unfavourable direction in which the inquest was heading, Hanna spent the closing hours of the inquest taking steps to ensure that Lowe was not charged with negligence. In many ways, Lowe was fortunate. Even Austin Stack was forced to admit that the inexperienced physician had in fact been the only person who had taken the time to check his pulse before commencing force-feeding. ${ }^{58}$ Dowdall and Cooke's handing over of the task of force-feeding to Lowe absolved them of direct blame, although their re-assignment was negatively commented upon.

Until the end of the inquest, Hanna remained determined to convince the jury that Thomas would still be alive had he not commenced a hunger strike. In his view, Thomas had died from a condition brought about only by himself and due to a weak heart condition which he had the misfortune to have been born with. 'It would be unfair', Hanna concluded, 'to lay the blame of his death on the shoulders of any one man', a final attempt at absolving Lowe. ${ }^{59}$ Ultimately, the jury concurred that Thomas had died of heart failure and congestion of the lungs caused by having his bed and boots removed and then being force-fed. The jury also concluded that Thomas had only gone on hunger strike to protest against the cruel punishment being inflicted on a class of prisoner who deserved special category status. Importantly, they condemned force-feeding as inhumane and dangerous and recommended its discontinuance in Ireland. ${ }^{60}$ Evidently, the attitudes of the prison staff towards its republican prisoners had mitigated against appropriate medical treatment. Ultimately, Thomas has been subjected to a series of punishments and feedings without proper attention being paid to his health. The violence and emotional trauma suffered 
by Thomas was brought to light in his inquest and cast disparity on the practice of force-feeding. The strong emotions sparked by force-feeding guaranteed that Dowdall and his colleagues found themselves at the epicentre of a broader political debate, conducted at a time of deep political tension, about the nature of British rule. They were cast as agents of an aggressive state willing to kill its political opponents rather than provide humane institutional conditions and grant politicised prisoners special category status.

\section{Conclusion}

At times of conflict, the medical ethical behaviour of prison medical staff has often been compromised by over-riding socio-political demands. Due to their 'dual loyalty' to their profession and the needs of the state, prison doctors have often found themselves embroiled in broader political debates when working in spaces of civil conflict. By virtue of being employed in a prison at a time of escalating socio-political discord, Dowdall came into contact with a number of politicised prisoners. Wittingly or not, he played an important role in helping the state confront political dissidents who had decided to hunger strike. Prisoner experiences varied. Dowdall exhibited skill and care while force-feeding suffragette prisoners, supporting the government's desire to avoid martyrdom. However, Mountjoy's staff seem to have held less favourable views towards republican prisoners, particularly those on hunger strike. They responded to prison protests with harsh punishments and careless force-feeding. The attitudes of prison medical staff towards these hunger strikers were clearly mediated through considerations including gender, nationality, and political perspectives. Negative perceptions of republicans as 'terrorists' and 'dissidents' encouraged prison experiences marred by violence and brutality. Prisoners experienced fear, resentment, and psychological distress upon being fed with a stomach tube. Thomas Ashes's death still occupies an important place in the emotional landscape of Irish republicanism; at the time it became upheld as a national occasion for grieving. Dowdall's participation in tackling political dissidence ultimately cast him in negative light. As Mountjoy's chief medical officer, he played a somewhat prominent role in the Irish revolution. His feedings were nationally reported and he was ultimately forced to provide evidence at a highly publicised inquest.

Analysis of Dowdall's career trajectory demonstrates that doctors can become subject to an array of professional and personal problems when 
called upon to force-feed politicised prisoners. The strain of managing large groups of recalcitrant prisoners places pressure on prison medical practice and encourages lapses in medical ethics less likely to occur in peacetime. Medical practice is deeply embedded in socio-political contexts. This is particularly the case at times of conflict. Politicised prisoners tend to be armed with the propaganda machines of their particular movements. Moreover, a death from force-feeding-publicly perceived as a painful, degrading, and unnecessary assault upon the body-can elicit sympathy and compassion even among those who do not support the agendas of political dissidents. Force-feeding casts prison doctors as perpetrators of violence and torture in a western socio-cultural climate that mostly abhors the idea of pain being inflicted upon individuals who have already lost their liberty. Claims that force-feeding amounts to therapeutic treatment generally prove unconvincing, a problem with significant implications for those doctors who choose to force-feed.

\section{Notes}

1. S. O'Cathasaigh, The Story of Thomas Ashe (Dublin: Fergus O'Connor, 1917), p. 11.

2. J. Sim, Medical Power in Prisons: The Prison Medical Service in England 1774-1989 (Milton Keynes and Philadelphia: Open University Press, 1990).

3. For a classic account, see Rosemary C. Owens, Smashing Times: A History of the Irish Women's Suffragette Movement, 1889-1922 (Dublin: Attic Press, 1984).

4. For an insightful overview of the various forms of nationalism present in early twentieth-century Ireland, see Thomas Hennessey, Dividing Ireland: World War One and Partition (London and New York: Routledge, 1998), pp. xi-xxi. For Unionism, see Paul Bew, Ideology and the Irish Question: Ulster Unionism and Irish Nationalism, 1912-16 (Oxford: Clarendon Press, 1994).

5. For the Ulster Volunteer Force, see T. Bowman, Carson's Army: The Ulster Volunteer Force, 1910-22 (Manchester: Manchester University Press, 2012). A standard text on the Irish Volunteers is F.X. Martin, The Irish Volunteers 1913-15: Recollections and Documents (Dublin: James Duffey, 1963).

6. See Michael Laffan, The Resurrection of Ireland: The Sinn Féin Party, 19161923 (Cambridge: Cambridge University Press, 1999).

7. Owen McGee, The IRB: The Irish Republican Brotherhood from the Land League to Sinn Féin (Dublin: Four Courts Press, 2007). 
8. Murphy, Political Imprisonment and the Irish.

9. Casualties had been reported in asylums. In 1912, suffragette newspaper, the Irish Citizen, reported on the inquest of a lunatic, James McGavigan, who had died at Letterkenny Lunatic Asylum, Co. Donegal, half an hour after being force-fed. McGavigan's stated cause of death was heart failure, an outcome used by the Irish Citizen to remind its readers 'of what this process really means and what it may involve'. See 'Forcible Feeding: Death of a Patient in an Irish Asylum', Irish Citizen (14 December 1912), p. 247.

10. Benjamin Gesundheit, Nachman Ash, Shraga Blazer and Avraham I. Rivkind, 'Medical Care for Terrorists: To Treat or not to Treat?', American Journal of Bioethics, 9:10 (2009), pp. 40-2.

11. For recent debate, see Jonathan H. Marks, 'The Terrorist and the Doctor: A Legal and Ethical Response', American Journal of Bioethics, 9:10 (2009), pp. 49-51; Michel Davis, 'Terrorists are Just Patients', American Journal of Bioethics, 9:10 (2009), pp. 56-7.

12. Minutes of Evidence of the Royal Commission on the Care and Control of the Feeble-Minded Volume III, Commons, Reports of Commissioners, 1908 [Cd. 4215], p. ix.

13. www.census.nationalarchives.ie/pages/1911/Dublin/Inn_s_Quay/ Mountjoy_Prison/18165. Accessed 15 May 2013, 11.32am.

14. British Journal of Nursing, 31 (19 September 1903), pp. 231-2.

15. 'Death at Mountjoy Prison', Irish Times (26 October 1908), p. 11.

16. Rosemary Cullen Owens, Smashing Times: A History of the Irish Women's Suffrage Movement, 1889-1922 (Dublin: Attic Press, 1984), pp. 24-5.

17. Owens, Smashing Times, pp. 41-2.

18. William Murphy, 'Suffragettes and the Transformation of Political Imprisonment in Ireland, 1912-1914', in Louise Ryan and Margaret Ward (eds), Irish Women and the Vote (Dublin: Irish Academic Press, 2007), pp. 114-35 on p. 129.

19. 'Dublin Suffragist Prisoners: Letter from Mr Bernard Shaw', Irish Times (17 September 1912), p. 7.

20. Miller, 'A Prostitution of the Profession', p. 229.

21. Murphy, 'Suffragettes and the Transformation of Political Imprisonment', p. 117.

22. Elaine Showalter, The Female Malady: Women, Madness and English Culture, 1830-1980 (London: Virago, 1987), pp. 162-4; Vernon, Hunger, p. 67.

23. Rachael Russell, 'Nausea and Vomiting: a History of Signs, Symptoms and Sickness in Nineteenth-Century Britain', Unpublished PhD thesis, University of Manchester, 2012, pp. 79-81.

24. National Archives of Ireland (hereafter NAI), GPB/SFRG/1/42, 'R. G. Dowdall, Medical Report', Autumn 1913. 
25. Showalter, Female Malady, pp. 162-4; Miller, 'A Prostitution of the Profession', pp. 236-40.

26. 'Suffragist Prisoner Released: Mrs Leigh taken to a Nursing Home', Irish Times (21 September 1912), p. 8.

27. 'Release of Miss Gladys Evans: Victory of Hunger Strikers', Irish Times (12 October 1912), p. 6.

28. NAI, GPB/SFRG/1/42, 'Newspaper Clippings', Freeman's Journal, 11 October 1913.

29. NAI, GPB/SFRG/1/18, 'List of Prisoners on Hunger Strike'.

30. NAI, GPB $/ 1 / 24$, 'Letter from Raymond G. Dowdall to General Prisons Board', 26 October 1913; 'Strapped to Torture Chair: Brutal Warders Recruited from the Hibernians; The Sufferings of Frank Moss', Daily Herald (26 February 1914), p. 2.

31. NAI, GPB/1915/3088.

32. Flynn, Pawns in the Game, p. 4.

33. George Sweeney, 'Irish Hunger Strikes and the Cult of Self-Sacrifice', Journal of Contemporary History, 28:3 (July 1993), pp. 421-37.

34. Murphy, 'Suffragettes and the Transformation of Political Imprisonment', p. 129.

35. Keith Jeffrey has noted that martial law was imposed during the Easter Rising primarily due to the circumstances of war. See Keith Jeffrey, Ireland and the Great War (Cambridge: Cambridge University Press, 2000), pp. 52-3.

36. Sikita Banerjee, Muscular Nationalism: Gender, Violence and Empire in India and Ireland, 1914-2004 (New York and London: New York University Press, 2012), pp. 45-57.

37. National Library of Ireland (hereafter NLI), MS44.612, 'Account of the Forcible Feeding at Mountjoy Prison resulting in the Death of Thomas Ashe', 20-25 September 1917, pp. 7-9.

38. Bureau of Military History (hereafter BMH), Witness Statement 1474, Eamon O'Dwyer, pp. 14-15.

39. Ibid., p. 12.

40. BMH, Witness Statement 942, Patrick J. Berry, p. 4.

41. Ibid., p. 5.

42. 'Account of Hunger Strike', pp. 19-23.

43. Ben Novick, Conceiving Revolution: Irish Nationalist Propaganda during the First World War (Dublin: Four Courts Press, 2001), p. 239.

44. Thomas Ashe, The Death of Thomas Ashe: Full Report of the Inquest (Dublin: J. M. Butler, 1917).

45. Ibid., p. viii.

46. Novick, Conceiving Revolution, pp. 236-9.

47. Frank Callanan, T. M. Healy (Cork: Cork University Press, 1996), p. 529. 
48. For a detailed account of the inquest, see Flynn, Pawns in the Game, pp. 27-38.

49. Ashe, Death of Thomas Ashe, pp. 4-5.

50. Ibid., p. 6.

51. Ibid., p. 7.

52. Fay Bound Alberti, Matters of the Heart: History, Medicine and Emotion (Oxford: Oxford University Press, 2010), pp. 153-6; Mark Jackson, The Age of Stress: Science and the Search for Stability (Oxford: Oxford University Press, 2013), p. 59.

53. Ashe, Death of Thomas Ashe, p. 15.

54. Ibid., p. 17.

55. Ibid., pp. 24-5.

56. Ibid., p. 28.

57. Ibid., p. 41.

58. Ibid., p. 80 .

59. Ibid., p. 82 .

60. Ibid., p. 93.

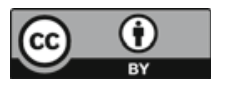

This chapter is distributed under the terms of the Creative Commons Attribution 4.0 International License (http://creativecommons.org/ licenses/by/4.0/), which permits use, duplication, adaptation, distribution and reproduction in any medium or format, as long as you give appropriate credit to the original author(s) and the source, provide a link to the Creative Commons license and indicate if changes were made.

The images or other third party material in this chapter are included in the work's Creative Commons license, unless indicated otherwise in the credit line; if such material is not included in the work's Creative Commons license and the respective action is not permitted by statutory regulation, users will need to obtain permission from the license holder to duplicate, adapt or reproduce the material. 